\title{
Front Matter: Volume 10597
}

, "Front Matter: Volume 10597," Proc. SPIE 10597, Nano-, Bio-, Info-Tech Sensors, and 3D Systems II, 1059701 (22 June 2018); doi: $10.1117 / 12.2324919$

Event: SPIE Smart Structures and Materials + Nondestructive Evaluation and SPIE. Health Monitoring, 2018, Denver, Colorado, United States 


\title{
PROCEEDINGS OF SPIE
}

\section{Nano-, Bio-, Info-Tech Sensors, and 3D Systems II}

\author{
Vijay K. Varadan \\ Editor \\ 5-7 March 2018 \\ Denver, Colorado, United States \\ Sponsored by \\ SPIE \\ Cosponsored by \\ Oz Optics, Ltd. (United States) \\ Polytec, Inc. (United States) \\ American Elements (United States) \\ Cooperating Organizations \\ Jet Propulsion Laboratory (United States) \\ Colorado Photonics Industry Association (United States) \\ Published by \\ SPIE
}


The papers in this volume were part of the technical conference cited on the cover and title page. Papers were selected and subject to review by the editors and conference program committee. Some conference presentations may not be available for publication. Additional papers and presentation recordings may be available online in the SPIE Digital Library at SPIEDigitallibrary.org.

The papers reflect the work and thoughts of the authors and are published herein as submitted. The publisher is not responsible for the validity of the information or for any outcomes resulting from reliance thereon.

Please use the following format to cite material from these proceedings:

Author(s), "Title of Paper," in Nano-, Bio-, Info-Tech Sensors, and 3D Systems II, edited by Vijay K. Varadan, Proceedings of SPIE Vol. 10597 (SPIE, Bellingham, WA, 2018) Seven-digit Article CID Number.

ISSN: 0277-786X

ISSN: 1996-756X (electronic)

ISBN: 9781510616905

ISBN: 9781510616912 (electronic)

Published by

SPIE

P.O. Box 10, Bellingham, Washington 98227-0010 USA

Telephone +1 3606763290 (Pacific Time) · Fax +1 3606471445

SPIE.org

Copyright (C) 2018, Society of Photo-Optical Instrumentation Engineers.

Copying of material in this book for internal or personal use, or for the internal or personal use of specific clients, beyond the fair use provisions granted by the U.S. Copyright Law is authorized by SPIE subject to payment of copying fees. The Transactional Reporting Service base fee for this volume is $\$ 18.00$ per article (or portion thereof), which should be paid directly to the Copyright Clearance Center (CCC), 222 Rosewood Drive, Danvers, MA 01923. Payment may also be made electronically through CCC Online at copyright.com. Other copying for republication, resale, advertising or promotion, or any form of systematic or multiple reproduction of any material in this book is prohibited except with permission in writing from the publisher. The CCC fee code is 0277$786 \mathrm{X} / 18 / \$ 18.00$.

Printed in the United States of America.

Publication of record for individual papers is online in the SPIE Digital Library.

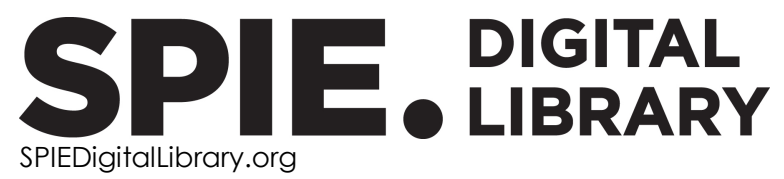

Paper Numbering: Proceedings of SPIE follow an e-First publication model. A unique citation identifier (CID) number is assigned to each article at the time of publication. Utilization of CIDs allows articles to be fully citable as soon as they are published online, and connects the same identifier to all online and print versions of the publication. SPIE uses a seven-digit CID article numbering system structured as follows:

- The first five digits correspond to the SPIE volume number.

- The last two digits indicate publication order within the volume using a Base 36 numbering system employing both numerals and letters. These two-number sets start with $00,01,02,03,04$, 05, 06, 07, 08, 09, OA, OB ... 0Z, followed by 10-1Z, 20-2Z, etc. The CID Number appears on each page of the manuscript. 


\title{
Contents
}

\author{
vii Authors \\ ix Conference Committee
}

WEARABLE AND IMPLANTABLE TECHNOLOGY AND HEALTHCARE II

$1059704 \quad$ New flexible RFID antennas using natural material [10597-2]

1059707 Design of an accelerometer to maximize the performance of vector hydrophones [10597-5]

NANOSENSORS AND SYSTEMS I

10597 OC DNT detection using microspheres coated with $\mathrm{NaYF}_{4}-\mathrm{Yb}^{3+}{ }^{3+} \mathrm{Er}^{3+}$-nanocrystals functionalized with PAA/PAH layers [10597-10]

\section{FABRICATION AND CHARACTERIZATION OF NANOSENSORS AND STRUCTURES I}

10597 OE Microwave characterization of graphene using an improved on-wafer calibration method [10597-12]

10597 OG Fabrication and characteristics of cellulose nanofiber films [10597-14]

$10597 \mathrm{OH} \quad$ Fabrication and characterization of cellulose nanofiber/graphene oxide blended fibers [10597-15]

\section{KEYNOTE SESSION I}

10597 OJ Military comparison of 3D printed vs commercial components (Keynote Paper) [10597-17]

3D PRINTING AND APPLICATIONS II

10597 OK Development of multi-material 3D printer [10597-18]

10597 OL Development of double network gel ring and evaluation of friction properties [10597-19] 
10597 OM Development of high-strength gel dosimeter made by 3D gel printer [10597-20]

10597 ON Investigating compression strengths of 3D printed polymeric infill specimens of various geometries [10597-21]

KEYNOTE SESSION II

10597 OP Cellulose nanocrystal based transparent electroactive polyurethane for active lens application (Keynote Paper) [10597-23]

\section{NANOSENSORS AND SYSTEMS II}

10597 OQ Properties of micro-nanofibrillated-chitin/bamboo-nanofiber nanocomposite [10597-24]

10597 OR Young's moduli of cellulose nanofibers measured by atomic force microscopy [10597-25]

10597 OS Alignment of cellulose nanofibers by high-DC magnetic field [10597-26]

WEARABLE MEDICAL DEVICES AND 3D PRINTING II

1059716 RepRap SWIM-ER: low cost open-source 3D gel printer [10597-45]

1059717 3D printing for gel robotics [10597-46]

1059718 3D printing of foods [10597-47]

1059719 Smart material for printing: piezo-electric polymer film [10597-48]

10597 1A Fabrication of a 3D nano-printing device [10597-49]

\section{POSTER SESSION}

10597 IB Stealth coating is not antidote against of microwave radiometer [10597-40]

10597 1C Yeast concentration analysis by using the portable microscope based on the fiber-optic array [10597-41]

10597 ID Hand gesture recognition using sparse autoencoder-based deep neural network based on electromyography measurements [10597-42]

iv 
$10597 \mathrm{lE}$ Soft capacitive sensors for measurement of both positive and negative pressures [10597-43]

$10597 \mathrm{IF} \quad$ Atomistic molecular dynamics study to investigate thermal response of cellulose nanofibrils using GROMACS [10597-44]

Proc. of SPIE Vol. 10597 1059701-5

Downloaded From: https://www.spiedigitallibrary.org/conference-proceedings-of-spie on 26 Apr 2023 Terms of Use: https://www.spiedigitallibrary.org/terms-of-use 
Proc. of SPIE Vol. 10597 1059701-6

Downloaded From: https://www.spiedigitallibrary.org/conference-proceedings-of-spie on 26 Apr 2023 Terms of Use: https://www.spiedigitallibrary.org/terms-of-use 


\section{Authors}

Numbers in the index correspond to the last two digits of the seven-digit citation identifier (CID) article numbering system used in Proceedings of SPIE. The first five digits reflect the volume number. Base 36 numbering is employed for the last two digits and indicates the order of articles within the volume. Numbers start with 00, 01, 02, 03, 04, 05, 06, 07, 08, 09, OA, OB...0Z, followed by 10-1Z, 20-2Z, etc.

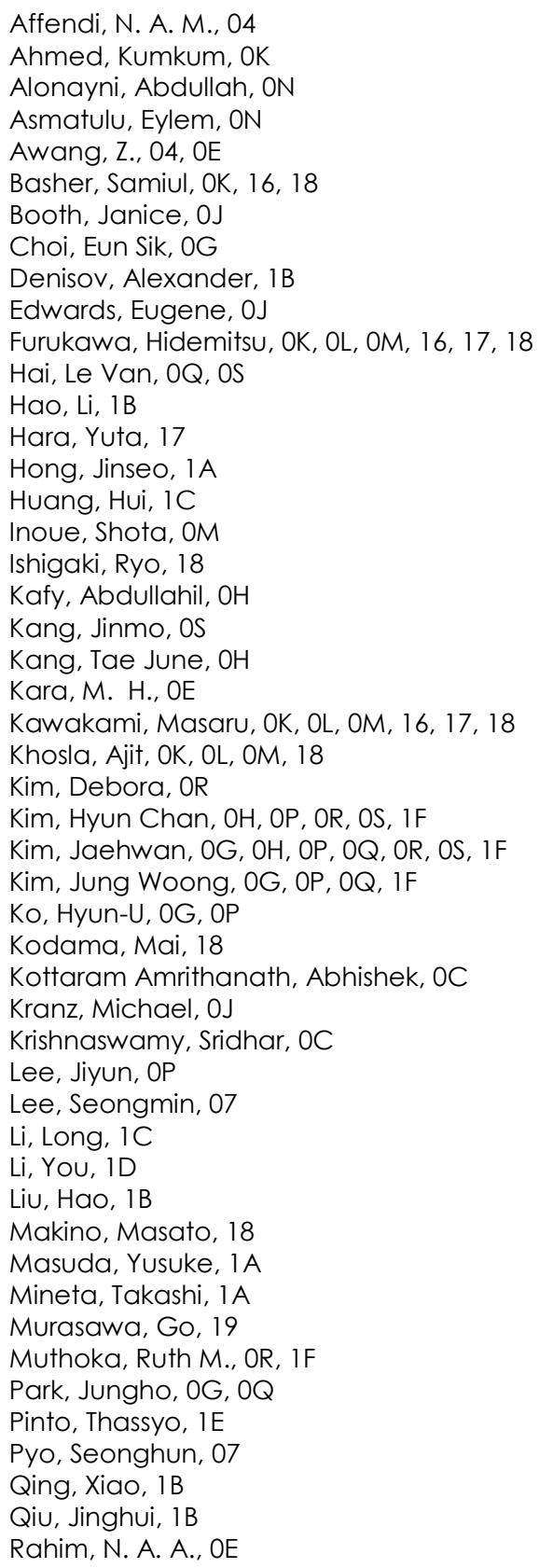

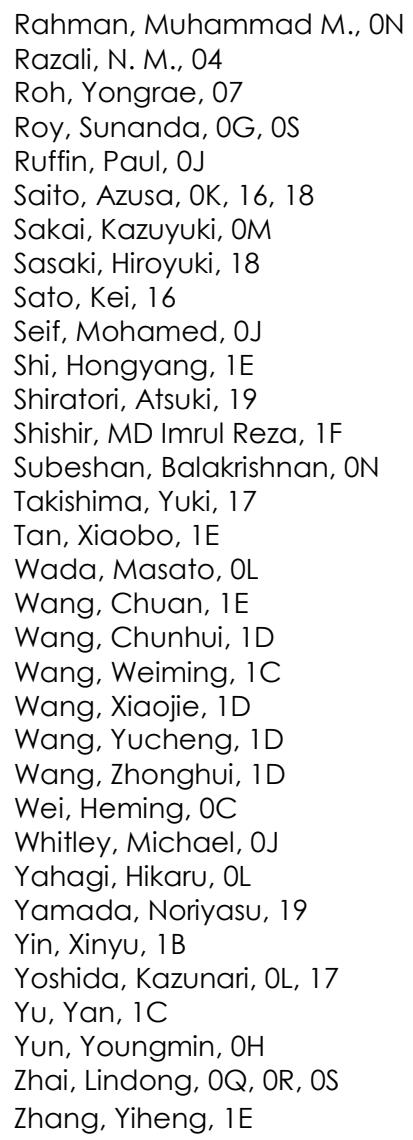


Proc. of SPIE Vol. 10597 1059701-8

Downloaded From: https://www.spiedigitallibrary.org/conference-proceedings-of-spie on 26 Apr 2023 Terms of Use: https://www.spiedigitallibrary.org/terms-of-use 


\title{
Conference Committee
}

\author{
Symposium Chairs
}

Tribikram Kundu, The University of Arizona (United States)

Gregory W. Reich, Air Force Research Laboratory (United States)

Symposium Co-chairs

Zoubeida Ounaies, The Pennsylvania State University (United States)

Hoon Sohn, KAIST (Korea, Republic of)

Conference Chair

Vijay K. Varadan, The Pennsylvania State University (United States)

Conference Co-chairs

Ajit Khosla, Yamagata University (Japan)

Hidemitsu Furukawa, Yamagata University (Japan)

Jaehwan Kim, Inha University (Korea, Republic of)

Kyo D. Song, Norfolk State University (United States)

Sang H. Choi, NASA Langley Research Center (United States)

Yongrae Roh, Kyungpook National University (Korea, Republic of)

Conference Program Committee

Anja Boisen, Technical University of Denmark (Denmark)

Christina L. Brantley, U.S. Army Research, Development and Engineering Command (United States)

Eugene Edwards, U.S. Army Research, Development and Engineering Command (United States)

Srinivasan Gopalakrishnan, Indian Institute of Science (India)

Seiich Hata, Nagoya University (Japan)

Taizo Hayashida, JSR Corporation (Japan)

Mamoru Kawakami, Yamagata University (Japan)

Kimiya Komurasaki, The University of Tokyo (Japan)

Hideki Kyogoku, Kindai University (Japan)

Uhn Lee, Gachon University Gil Medical Center (Korea, Republic of)

Go Murasawa, Yamagata University (Japan)

Hani E. Naguib, University of Toronto (Canada)

Ilkwon Oh, KAIST (Korea, Republic of)

Aswini K. Pradhan, Norfolk State University (United States)

D. Roy Mahapatra, Indian Institute of Science (India) 
Paul B. Ruffin, Alabama A\&M University (United States)

Ashok Srivastava, Louisiana State University (United States)

Hiroya Tanaka, Keio University (Japan)

Tauno Vaha-Heikkila, VTT Technical Research Center of Finland

(Finland)

Wei-Chih Wang, University of Washington (United States)

Hargsoon Yoon, Norfolk State University (United States)

\section{Session Chairs}

1 Wearable and Implantable Technology and Healthcare I

Vijay K. Varadan, The Pennsylvania State University (United States)

2 Wearable and Implantable Technology and Healthcare II

Vijay K. Varadan, The Pennsylvania State University (United States)

3 Additive Manufacturing and 3D Printing

Kyo D. Song, Norfolk State University (United States)

4 3D Printing and Applications I

Ajit Khosla, Yamagata University (Japan)

$5 \quad$ Nanosensors and Systems I

Vijay K. Varadan, The Pennsylvania State University (United States)

6 Fabrication and Characterization of Nanosensors and Structures I

Jaehwan Kim, Inha University (Korea, Republic of)

$7 \quad$ Keynote Session I

Vijay K. Varadan, The Pennsylvania State University (United States)

8 3D Printing and Applications II

Kumkum Ahmed, Yamagata University (Japan)

9 Keynote Session II

Vijay K. Varadan, The Pennsylvania State University (United States)

10 Nanosensors and Systems II

Kyo D. Song, Norfolk State University (United States)

11 Nanosensors and Systems III

Vijay K. Varadan, The Pennsylvania State University (United States)

12 Keynote Session III

Sang H. Choi, NASA Langley Research Center (United States) 
13 Nanomaterials and Applications

Ajit Khosla, Yamagata University (Japan)

14 Wearable Medical Devices and 3D Printing I

Vijay K. Varadan, The Pennsylvania State University (United States)

15 Wearable Medical Devices and 3D Printing II

Ajit Khosla, Yamagata University (Japan)

Hidemitsu Furukawa, Yamagata University (Japan)

3D Printing Demonstration Session

Ajit Khosla, Yamagata University (Japan)

Hidemitsu Furukawa, Yamagata University (Japan) 
Proc. of SPIE Vol. 10597 1059701-12 Downloaded From: https://www.spiedigitallibrary.org/conference-proceedings-of-spie on 26 Apr 2023
Terms of Use: https://www.spiedigitallibrary.org/terms-of-use 